KAssanis, B. (1953). J. gen. Microbiol. 9, 467-474.

\title{
Some Effects of Sucrose and Phosphorus in increasing the Multiplication of Tobacco Mosaic Virus in detached Tobacco Leaves
}

\author{
By B. KASSANIS \\ Rothamsted Experimental Station, Harpenden, Hertfordshire
}

\begin{abstract}
SUMMARY : Tobacco mosaic virus reached higher concentrations when inoculated tobacco leaves were placed in a solution containing $10 \mathrm{~g} . /$. sucrose and $0.2 \mathrm{~g} . / \mathrm{l}$. calcium phosphate than when in water. Detached leaves in water usually produced more virus than leaves left on the plants. Other sugars and phosphates also increased virus production. Sugar and calcium phosphate sometimes separately increased the concentration of the virus, but the response was usually greatest to both together. The increase varied with the nutritional state of the plants from which the leaves came and some other environmental conditions. Virus concentration, and the effect of sucrose and calcium phosphate in increasing it, was greater when leaves were in the light than in the dark. Conditions which increased virus concentration also increased the total carbohydrates of the leaves.
\end{abstract}

The effect of various substances on the multiplication of tobacco mosaic virus has been studied in detached tobacco leaves or in disks cut from the leaves. Most of such work has been done to find substances that inhibit multiplication, and there have been few experiments to find conditions under which the virus multiplies most extensively, although work with whole plants has demonstrated that host nutrition and environment both affect virus production. The experiments described below show that virus production is greater in detached leaves placed in solutions containing sugar and phosphate than in water, and that the extent to which sugar and phosphate affect virus multiplication varies with the physiological conditions of the leaves and depends on whether they are kept in the light or dark.

\section{MATERIALS AND METHODS}

The experiments were made with tobacco mosaic virus in tobacco (Nicotiana tabacum $\mathrm{L}$. var. White Burley), using for inoculum a purified virus preparation at a concentration of $1 \mathrm{~g}$./l. Quantitative infectivity tests were made by the local-lesion method, using Nicotiana glutinosa $\mathrm{L}$. The tobacco leaves were detached from the plants a day after their inoculation and placed in distilled water or in solutions of the different substances being tested. This interval between inoculation and treatment was adopted to avoid the diminution in the number of local infections produced by floating leaves immediately after they are inoculated, a phenomenon that has also been described by Yarwood, Hall \& Nelson (1953). Two to four tobacco plants provided the six to twelve leaves which were inoculated for every treatment; from these a total of 15-20 ml. of sap was extracted. The leaves were placed in shallow enamel 
dishes measuring $0 \cdot 25-0.30 \mathrm{~m}$. and containing a litre of the fluid; about half the total leaf surface was submerged. The dishes were covered with glass and, unless otherwise mentioned, kept in a glasshouse with a mean temperature of $20^{\circ}$ for 5-8 days. Bacterial growth was checked by adding 0.3 g. sulphanilamide/l. fluid; this has no effect on virus multiplication, but usually kept the fluids clear and the leaves turgid until the end of the experiment. When the solution contained a nitrogenous substance it became turbid and the leaves slimy, but by changing the fluids after 3 days bacterial growth was kept below the level at which the leaves suffered. The floated leaves usually became chlorotic and sometimes developed local lesions, showing as green rings or spots against the yellow background of the leaf. The lesions appeared more often in leaves placed in nutrient solutions than in water.

At the end of the experiment the leaves were washed in tap-water, dried with a towel and ground in a mortar. The sap was extracted through muslin, heated at $60^{\circ}$ for $10 \mathrm{~min}$. and centrifuged. The virus was quantitatively isolated from $10 \mathrm{ml}$. of clarified sap by precipitating twice with 1/4-saturated ammonium sulphate solution and once at $\mathrm{pH} \mathrm{3 \cdot 3}$. The preparations were freed from salts by denaturing the virus with trichloroacetic acid, washing the denatured protein 3 times in distilled water and centrifuging. The protein was then dried in an oven and weighed. By this method $90 \%$ of the virus present in the sap was recovered.

\section{EXPERIMENTAL \\ Sucrose and phosphate}

Table 1 records the results of three experiments to compare the concentration of tobacco mosaic virus in tobacco leaves placed for 5 days in water or in a nutrient solution containing $5 \mathrm{~g}$. sucrose/l. and $0.2 \mathrm{~g}$. $/$. each of $\mathrm{NH}_{4} \mathrm{NO}_{3}$ and $\mathrm{Ca}\left(\mathrm{H}_{2} \mathrm{PO}_{4}\right)_{2} \cdot \mathrm{H}_{2} \mathrm{O}$. Exps. $\mathrm{A}$ and $\mathrm{B}$ had three replications and Exp. $\mathrm{C}$ two replications for each treatment. The leaves placed in the nutrient contained from 50 to $70 \%$ more virus than the leaves in water. The replications differed little. Statistical analysis showed the difference to be significant between 1 and $0.1 \%$ probability level and in Exp. $\mathrm{C}$ between 2 and $1 \%$. Although replications in individual experiments differed little, there were considerable differences in virus concentration with similar treatments in experiments done

Table 1. The concentration of tobacco mosaic virus in leaves placed in water and in nutrient solution

\begin{tabular}{|c|c|c|c|}
\hline \multirow[b]{2}{*}{ Fluid } & \multicolumn{3}{|c|}{$\begin{array}{c}\text { Exp. A } \\
\text { mg. virus/ml. sap }\end{array} \underset{\text { Exp. B }}{\text { Exp. C }}$} \\
\hline & & $\mathrm{I}^{1}$ & \\
\hline \multirow[t]{3}{*}{ Water } & 1.2 & $0 \cdot 9$ & 0.9 \\
\hline & $1 \cdot 3$ & $1 \cdot 1$ & $1 \cdot 0$ \\
\hline & $1 \cdot \mathbf{3}$ & $1 \cdot 0$ & - \\
\hline \multirow{3}{*}{ Nutrient solution } & $\mathbf{2 \cdot 0}$ & 1.5 & 1.5 \\
\hline & $\mathbf{2 \cdot 2}$ & $1 \cdot 4$ & $1 \cdot 6$ \\
\hline & $2 \cdot 4$ & $1 \cdot 7$ & 一 \\
\hline $\begin{array}{l}\text { Difference between means } \\
\text { s.E. of the difference }\end{array}$ & $\begin{array}{l}0 \cdot 9 \\
0 \cdot 120\end{array}$ & $\begin{array}{l}0.5 \\
0.105\end{array}$ & $\begin{array}{l}0 \cdot 6 \\
0.071\end{array}$ \\
\hline
\end{tabular}


at different times. In winter, for example, the inoculated leaves contained much less virus than in the summer; nutrient solution also had a proportionally greater effect on virus concentration in winter.

The concentration of virus depended on the amount of sucrose in the nutrient solution, and preliminary tests showed that most virus was usually obtained with $10 \mathrm{~g}$. sucrose/l. in combination with $\mathbf{0 . 2}$ g. calcium phosphate/l. These concentrations were used throughout the rest of the experiments.

Of sucrose, $\mathrm{NH}_{4} \mathrm{NO}_{3}, \mathrm{Ca}\left(\mathrm{H}_{2} \mathrm{PO}_{4}\right)_{2} \cdot \mathrm{H}_{2} \mathrm{O}$ present in the nutrient solution, only sucrose and calcium phosphate affected virus production, and whereas each separately often had little effect the two together usually produced a large response. To quote one experiment in which inoculated leaves were placed in

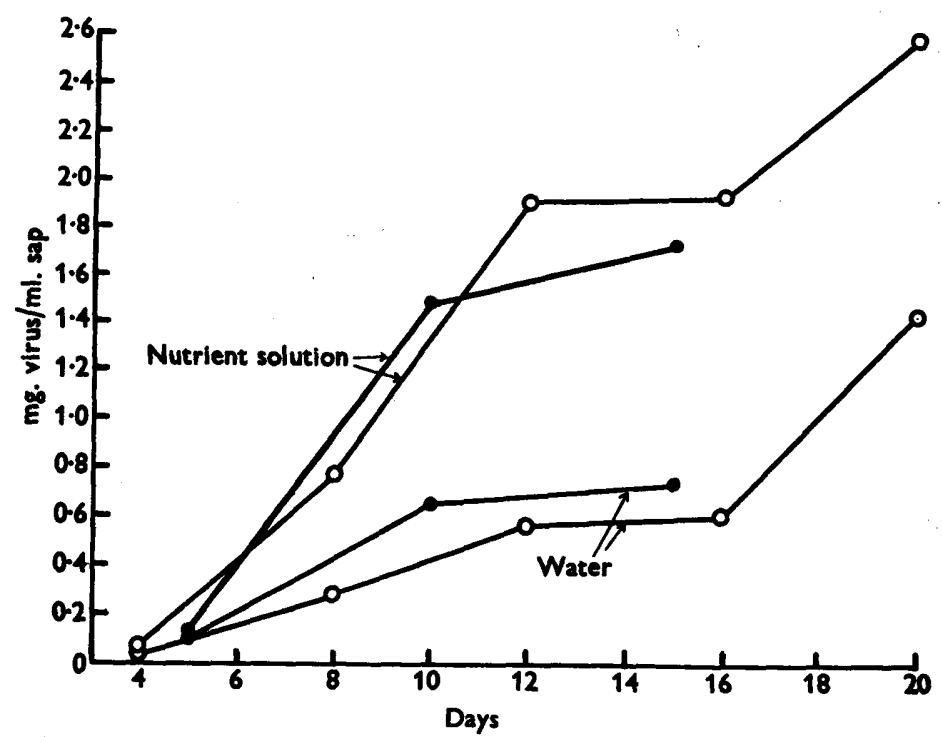

Fig. 1. The concentration of tobacco mosaic virus in sap (mg./ml.) from tobacco leaves placed in water or nutrient solution at different times from inoculations. Exp. A, - ; Exp. B, O-O.

water, a solution of calcium phosphate alone, of sucrose alone, and a mixture of the two, the amount of virus in sap was $0.5,0.5,0 \cdot 6$ and $1.1 \mathrm{mg} . / \mathrm{ml}$, respectively. In a few experiments, however, there was a good response to phosphate or sugar when given alone, and some of the conditions for such a response are described later. Potassium or ammonium phosphate behaved like calcium phosphate. Glucose, fructose, mannose, lactose and raffinose all increased the virus concentration to the same extent as did sucrose. Mannitol had a smaller effect and arabinose none.

Nutrient solutions that greatly increased virus concentration when inoculated leaves were placed in them had little effect when leaves were left on the plant and sprayed with them. The mean yield of virus in sap from two replications in one experiment was (mg./ml.): leaves placed in water $0 \cdot 7$, placed in nutrient solution $2 \cdot 1$, leaves left on the plant and sprayed with water $0 \cdot 4$, leaves sprayed with nutrient solution $0 \cdot 5$. In this, as in seven out of fourteen 
experiments, sap from detached leaves placed in water contained more virus than sap from leaves left on the plant; in five of the other experiments there was no difference.

The difference in virus content between leaves placed in water and in nutrient solutions was maintained for longer than the 5-8 days for which most experiments ran. Fig. 1 gives results of two experiments in which inoculated leaves in water and in nutrient solution were sampled at different intervals up to 20 days after inoculation and shows that differences became apparent after 4) days and were maintained throughout. The leaves could not be kept longer, because, even with frequent changes of solutions, they became very chlorotic after 15-20 days.

\section{Nitrogen}

Virus multiplication was usually unaffected by the presence of a nitrogenous source in the solution, with or without sucrose and phosphate. In one typical experiment with solutions containing $10 \mathrm{~g}$. sucrose/l. and $0.2 \mathrm{~g}$. calcium phosphate/l., the mean yield of virus in sap for two replications was $1.45 \mathrm{mg}$./ ml. with ammonium sulphate, $0 \cdot 2 \mathrm{~g}$. $/ 1$. and $1 \cdot 40$ without it. In a few experiments the addition of nitrogen decreased virus concentration and in a few made in the summer increased it. Increases occurred with leaves taken from plants showing signs of nitrogen deficiency, and in such leaves virus production was increased by sucrose and phosphate only when nitrogen was added. The way in which the nutritional state of the plants at the time of inoculation influenced the effects of nutrient solution on the virus multiplication was shown by experiments with plants given different nutrients. Half of one group of nitrogendeficient plants were given ammonium sulphate $1 \mathrm{~g}$. per pot 2 weeks before inoculation. Half of the inoculated leaves in each group were placed in water and half in a solution containing sucrose and calcium phosphate. The concentration of virus in sap from the plants that received ammonium sulphate was (mg./ml.): 0.3 from leaves in water and 1.0 from leaves in solution; from the plants which did not receive ammonium sulphate 0.4 from leaves in water and $\mathbf{0 . 6}$ from leaves in solution.

\section{Effect of light}

Takahashi (1947) found that more tobacco mosaic virus was present in inoculated leaves detached and kept in the light than from those kept in the dark. The effect of light in stimulating virus production was confirmed in my tests with sucrose and calcium phosphate. Table 2 gives the results of one experiment in which the inoculated leaves, either left on the plant or detached, were kept either in light or in the dark, until harvest. Statistical analysis of the results showed that the virus concentration in leaves in nutrient solution was significantly higher $(P=1 \%)$ than that in leaves in water or on the plant. The concentration of virus in leaves in the light was significantly higher $(P=1-0.1 \%)$ than in leaves in the dark. but there was no interaction between light and nutritional treatment.

In this, and in other experiments when estimations were made for carbohydrates in expressed sap, leaves in nutrient solution contained more than 
those kept in water, and much more when in the light than in the dark. Iodine staining also showed considerable differences in the amount of starch formed in the leaves treated differently. The leaves in water had little starch when kept in the light and none in the dark, whereas leaves in the nutrient solution stained heavily when kept in the light, but only a band of cells at the end of the petioles stained heavily when leaves were in the dark. This difference in starch content was also obvious when the sap was centrifuged. Starch forms a distinct white zone in the sediment, and the size of this zone varied strikingly with the previous treatment of the leaves.

Table 2. The effect of sucrose and phosphate on tobacco mosaic virus in tobacco leaves in the light and dark

\begin{tabular}{|c|c|c|c|c|c|}
\hline \multirow[b]{2}{*}{$\begin{array}{c}\text { Treatment of } \\
\text { the leaves }\end{array}$} & \multicolumn{3}{|c|}{ Light } & \multicolumn{2}{|c|}{ Dark } \\
\hline & $\begin{array}{c}\text { Total } \\
\text { carbohydrate } \\
\text { in sap } \\
\text { (mg./ml.) }\end{array}$ & $\begin{array}{c}\text { Phosphorus } \\
\text { in sap } \\
(\mu \mathrm{g} . / \mathrm{ml} .)\end{array}$ & $\begin{array}{c}\text { Virus } \\
\text { in sap } \\
(\mathrm{mg} / \mathrm{ml} .)\end{array}$ & $\begin{array}{c}\text { Total } \\
\text { carbohydrate } \\
\text { in sap } \\
\text { (mg./ml.) }\end{array}$ & $\begin{array}{c}\text { Virus } \\
\text { in sap } \\
(\mathbf{m g} \cdot / \mathbf{m l} .)\end{array}$ \\
\hline Left on the plant & 89 & 87 & 0.8 & $\mathbf{3}$ & 0.5 \\
\hline Placed in water & 9 & 96 & 0.6 & $\mathbf{3}$ & 0.4 \\
\hline Placed in $10 \mathrm{~g}$. sucrose/l. & 23 & 274 & $1 \cdot 1$ & 8 & $0 \cdot 6$ \\
\hline
\end{tabular}

All figures are means of two replications. The standard error of the concentration of virus is $\mathbf{0 . 0 6 7}$.

\section{Phosphorus}

Table 2 gives the phosphorus content of sap from the leaves in the light, and shows that these take up much phosphorus from the fluid. In other experiments, when phosphorus estimation was made on sap from leaves left in the light or dark, the amount in both was the same. That phosphorus is taken in quite readily was also shown by placing inoculated leaves in solutions in which $\mathrm{KH}_{2} \mathrm{PO}_{4}$ containing radioactive phosphorus was added. Indeed, this proved a better method of producing radioactive tobacco mosaic virus, than giving 32P through roots. When tobacco plants are grown in water culture containing high concentration of ${ }^{22} \mathrm{P}$ their roots are damaged (Russell, Adams \& Martin, 1949) so that the yield and radioactivity of the virus is lower than that from inoculated leaves placed in nutrient containing ${ }^{32} \mathbf{P}$. From leaves placed in a nutrient containing $10 \mathrm{~g}$. sucrose $/ 1$. and $300-400 \mu \mathrm{C}$ of ${ }^{32} \mathrm{P}$ and $0 \cdot 1 \mathrm{~g}$. $\mathrm{KH}_{2} \mathrm{PO}_{4} / 1$, tobacco mosaic virus was isolated 6 days later and had a specific activity of about $0.025 \mu \mathrm{C} / \mathrm{mg}$. protein. On this occasion $40 \mathrm{~g}$. leaves gave $30 \mathrm{mg}$. purified virus. The infectivity of the radioactive virus per unit weight was the same as that of virus isolated from leaves placed in water or leaves left on the plant.

Sucrose and phosphate usually interacted strongly in increasing the concentration of tobacco mosaic virus. In some experiments, however, one of the two substances was responsible for most of the increase. In one experiment with such a result, the pots of half of the plants were watered 5 times with $20 \mathrm{ml}$. of $5 \mathrm{mg}$. calcium phosphate/ml. before the plants were inoculated. The yield of virus in sap with the watered plants was $(\mathrm{mg} . / \mathrm{ml}):. 0 \cdot 6$ in water, 1.1 in sucrose, 1.1 in sucrose and calcium phosphate; for the unwatered plants it was $0 \cdot 8,1 \cdot 3,1 \cdot 9$, respectively, for the three treatments. 


\section{Other factors}

Leaves from young and old plants responded equally well to sucrose and calcium phosphate. In one experiment the concentration of virus in sap was (mg./ml.): 0.7 and 1.4 for the young plants and 0.4 and 0.9 for the old plants, respectively, for leaves in water and in the nutrient solution. The higher virus concentration in young leaves probably occurred because inoculation produced more foci of infection. Virus production is also greater when inoculations are made with the aid of an abrasive, such as 'Celite', when the response to sucrose and calcium phosphate is also often proportionally greater than in comparable leaves inoculated without 'Celite'. Table 3 gives the results of two experiments on the effect of 'Celite' and of two experiments in which the inoculated leaves (without 'Celite') were kept continuously at $36^{\circ}$ and compared with leaves at fluctuating glasshouse temperature with a mean of $20^{\circ}$. The leaves in water at $36^{\circ}$ contained little virus, but phosphorus and sucrose had a proportionally bigger effect on virus content at $86^{\circ}$ than at $20^{\circ}$. This probably occurred because the sucrose in the solution compensated for the carbohydrates lost by greater respiration at $36^{\circ}$ than at $20^{\circ}$. At the end of Exp. A (Table 3) the total carbohydrates in crude sap for leaves were ( $\mathrm{mg} . / \mathrm{ml}$.): at $20^{\circ}, 12.5$ and $28 \cdot 7$, and at $36^{\circ}, 6.9$ and 28.6 respectively for water control and nutrient solution.

Table 3. The effect of sucrose and phosphate on tobacco mosaic virus in leaves inoculated by different methods and left at different temperatures

\begin{tabular}{|c|c|c|c|c|c|c|c|c|}
\hline \multirow{2}{*}{ Treatment } & \multicolumn{2}{|c|}{ Without 'Celite' } & \multicolumn{2}{|c|}{ With 'Celite' } & \multicolumn{2}{|c|}{$20^{\circ}$} & \multicolumn{2}{|c|}{$36^{\circ}$} \\
\hline & Exp. A & Exp. B & Exp. A & $\begin{array}{l}\text { Exp. B } \\
\text { virus mg }\end{array}$ & $\begin{array}{l}\text { Exp. A } \\
\text {. } / \mathrm{ml} \text {. sap }\end{array}$ & Exp. B & Exp. A & Exp. B \\
\hline Water & 0.4 & 0.5 & 0.9 & 0.7 & 0.9 & 1.0 & 0.2 & $0 \cdot 1$ \\
\hline $\begin{array}{l}\text { Nutrient containing } \\
10 \text { g. sucrose/l. and } \\
0 \cdot 2 \text { g. calcium } \\
\text { phosphate/l. }\end{array}$ & 0.8 & 0.8 & $\mathbf{2 \cdot 0}$ & $\mathbf{2 \cdot 3}$ & 1.7 & $2 \cdot 0$ & 0.7 & 0.7 \\
\hline
\end{tabular}

Yarwood (1952b) found that $31^{\circ}$ was the optimal temperature for tobacco mosaic virus multiplication, and he could not detect virus in infected leaves kept at $37^{\circ}$. Although the virus does multiply at $36^{\circ}$ (Table 3 ) this temperature is clearly far from optimal.

\section{DISCUSSION}

The results obtained with tobacco mosaic virus in tobacco plants may not apply generally to other viruses or hosts. Yarwood (1952a), testing the effect of sucrose on the multiplication of some viruses in inoculated leaves kept in the dark, found considerable differences between different virus-host combinations. His assays were made by inoculation to French beans and were expressed as lesions produced by extracts from equal weight of macerated leaf tissue. He found that tobacco mosaic virus in tobacco produced twice as many lesions in French beans when the inoculum was from leaves in $10 \%$ sucrose than in water, but has questioned the significance of this difference. With 
some other virus-host combinations he found different results. For example, the concentration of tobacco mosaic virus in French beans was higher in leaves placed in sucrose solution than in water, whereas tobacco ring spot virus in French beans gave the opposite results. Leben \& Fulton (1952), searching for a method for screening the effect of different substances on viruses in vivo, found that tobacco necrosis and tobacco ring spot viruses produced lesions on detached cowpea leaves in the dark only when the medium supplied to the leaves contained sucrose.

In my experiments the leaves given sucrose not only had a greater virus content than in water but also accumulated considerable amounts of starch and other carbohydrates. This suggests that sucrose was not acting merely as a substrate for the energy required for virus multiplication but was generally stimulating cell metabolism. As protein synthesis can take place in the dark, provided there is a source of carbohydrate, it is rather unexpected that sucrose in the dark has a smaller effect than in the light. Analysis showed that the total carbohydrates were also low in leaves left in the dark, possibly because less sucrose was taken in by leaves in the dark than in the light. Phillis \& Mason (1937) reported a similar observation; using disks of leaves previously destarched and immersed in solution of sucrose, no starch, or very little, was formed in the dark, whereas even diffuse daylight, insufficient for assimilation, promoted starch formation.

Placing detached leaves in the nutrient solution increased the virus concentration more than did spraying the solution on the leaves left on the plants. Less sucrose may enter the sprayed leaves, but detaching the leaves may also result in more favourable conditions for virus multiplication. Vickery $e t a l$. (1987) found that protein hydrolysis is stimulated by detaching tobacco leaves and proceeds rapidly both in light and dark for the first $72 \mathrm{hr}$. It is likely, then, that the virus finds the material for its synthesis ready-made in detached leaves.

The effect of phosphorus in increasing the multiplication of tobacco mosaic virus may simply be a consequence of the leaves usually containing less than the optimal amount. This is suggested by the results of one experiment in which plants were given extra phosphorus before inoculation. However, Bawden \& Kassanis (1949), and Cheo, Pound \& Weathers (1952), found that the concentration of tobacco mosaic and cucumber mosaic viruses, respectively, in plants was increased by increasing phosphorus to levels at which the growth of the plants was reduced.

I am indebted to Mr H. L. Nixon for measuring the radioactivity of the virus preparations containing ${ }^{3 a}$.

\section{REFERENCES}

Bawden, F. C. \& Kassanis, B. (1949). Some effect of host-plant nutrition on the multiplication of viruses. Ann. appl. Biol. 37, 215.

Cheo, P. C., Pound, G. S. \& Weathers, L. G. (1952). The relation of host nutrition to the concentration of cucumber virus 1 in spinach. Phytopathology, 42, 377.

Leben, C. \& Fulton, R. W. (1952). The effect of certain antibiotics on lesion production by two plant viruses. Phytopathology, 42, 331. 
Philus, E. \& Mason, T. G. (1937). On the effect of light and of oxygen on the uptake of sugar by the foliage leaf. Mem. Cott. Res. Sta., Trinidad, ser. B, no. 10.

Russely, R. S., Adams, S. N. \& Martin, R. P. (1949). Radiation effects due to phosphorus -32 in fertilizer experiments. Nature, Lond. 164, 993.

Takahashr, W. N. (1947). Respiration of virus infected plant tissue and effect on virus multiplication. Amer. J. Bot. 34, 496.

Vickery, H. B., Pucher, G. W., Wakgman, A. J. \& Leavenworth, C. S. (1937). Chemical investigations of the tobacco plant. VI. Chemical changes that occur in leaves during culture in light and in darkness. Bull. Conn. agric. Exp. Sta. no. 399.

YARwOOD, C. E. (1952a). Some relations of carbohydrate level of the host to plant virus infections. Amer. J. Bot. 39, 119.

YARwOOD, C. E. (1952b). Latent period and generation time for two plant viruses. Amer. J. Bot. 39, 613.

Yarwood, C. E., HALL, A. P. \& NeLson, M. N. (1953). Nutritive value of rustinfected leaves. Science, 117, 326.

(Received 6 June 1953) 